\title{
Neonatal Screening for Sickel Cell Disease in Urban Areas with Limited Resources: Case of Kindu City, East of the Democratic Republic of Congo
}

\author{
Antoine Lufimbo Katawandja ${ }^{1,2 *}$, Franck Nzengu-Lukusa ${ }^{3,4}$, \\ Donatien Kayembe Nzongola-Nkasu3 ${ }^{3}$, Léon Tshilolo Muepu, 4,5
}

\begin{abstract}
${ }^{1}$ Department of Basic Sciences, Faculty of Medicine, University of Kindu, Kindu, Democratic Republic of Congo
${ }^{2}$ Laboratory Service, Lumbulumbu Hospital Center/MAPON Clinic, Kindu, Democratic Republic of Congo

${ }^{3}$ Department of Medical Biology, University Clinics of Kinshasa, Kinshasa, Democratic Republic of Congo

${ }^{4}$ Laboratory Service, Monkole Hospital Center, Kinshasa, Democratic Republic of Congo

${ }^{5}$ Health Training and Support Center (CEFA/Monkole), Kinshasa, Democratic Republic of Congo

Email: ^dralkalufimbo@gmail.com, francknzengulukusa@gmail.com, kayembe.donatien@gmail.com,

Leon.tshilolo2012@gmail.com
\end{abstract}

How to cite this paper: Katawandja, A.L., Nzengu-Lukusa, F., Nzongola-Nkasu, D.K. and Muepu, L.T. (2021) Neonatal Screening for Sickel Cell Disease in Urban Areas with Limited Resources: Case of Kindu City, East of the Democratic Republic of Congo. Open Access Library Journal, 8: e7097.

https://doi.org/10.4236/oalib.1107097

Received: December 19, 2020

Accepted: January 26, 2021

Published: January 29, 2021

Copyright $\odot 2021$ by author(s) and Open Access Library Inc.

This work is licensed under the Creative Commons Attribution International License (CC BY 4.0).

http://creativecommons.org/licenses/by/4.0/

(c) (i) Open Access

\begin{abstract}
Introduction: The Democratic Republic of Congo is the third most affected country in the world by sickle cell disease (SCD) after India and Nigeria. However, the available data on sickle cell disease in the DRC are piecemeal and do not reflect the current reality of the country. Conventional equipment recommended for neonatal screening for sickle cell disease (IEF, HPLC) is not available in Kindu. Currently, a simple, effective and affordable technique, the Sickel SCAN ${ }^{\circledR}$ Rapid Screening Test (RST), has been validated nationally in the Nsonso MD (2017) study. The aim of this study was to detect sickle cell disease in neonates in nine maternity homes in the city of Kindu by Sickle SCAN ${ }^{\circledR}$. Methods: This is a descriptive cross-sectional study that involved newborns in nine maternity homes in the city of Kindu during the period from 01 June to 31 July 2018. Results: 310 newborns were screened, divided into 164 girls against 146 boys. $26.8 \%$ of newborns were diagnosed with sickle cell trait $(n=83) ; 1.9 \%$ were homozygous sickle cell $(n=6)$. Of all the newborns screened for SCD, there was no significant difference between the sexes: $50.6 \%$ were males vs. $49.4 \%$ females. Neonates diagnosed with homozygous sickle were from Lega $(\mathrm{n}=3)$, Kusu $(\mathrm{n}=1)$, Kasenga $(\mathrm{n}=1)$ and Zimba $(n=1)$ tribes. Conclusion: The neonatal prevalence of sickle cell disease in the homozygote found in Kindu is almost similar to the actual prevalence of WHO in the DRC (2\%).
\end{abstract}




\section{Subject Areas}

Gynecology \& Obstetrics, Pediatrics

\section{Keywords}

Neonatal Screening, Sickle Cell Disease, Rapids Tests, Kindu

\section{Introduction}

Sickle cell disease affects 20 - 25 million people globally, including 12 to 15 million in Africa, $50 \%$ to $80 \%$ of children with homozygous sickle cell disease in Africa die before the age of 5 [1]. Thus, the United Nations (UN) has recognized sickle cell anemia as a global public health problem in terms of mortality, morbidity and significant socio-economic impact associated with the disease [2]. The economic consequences of this disease are catastrophic for populations who already live in extreme poverty. In Burkina-Faso, it is estimated at one hundred and eighty-four US dollars point eighty-eight cents (\$184.88), the average cost of care, in hospitalization, of a sickle cell child. In the United States of America (USA) and in the Democratic Republic of Congo (DRC), the annual costs of caring for a child with homozygous sickle cell disease are respectively one thousand three hundred and eighty-nine (\$1389) and one thousand US dollars (\$1000) [3] [4].

Indeed, the life expectancy of sickle cell patients can be greatly improved by an early diagnosis, especially when it is done in the neonatal period, followed by education of parents in simple daily actions, adequate management by therapeutic measures. prophylactics. With this strategy, the World Health Organization (WHO) estimates that $70 \%$ of deaths are preventable. Sickle cell disease is particularly common in people from sub-Saharan Africa, India, Saudi Arabia and Mediterranean countries. Migration has increased the frequency of the offending gene in America. In parts of sub-Saharan Africa, homozygous sickle cell disease affects up to $2 \%$ of newborns. More broadly, the prevalence of sickle cell trait reaches $10 \%$ to $40 \%$ in Equatorial Africa, $1 \%$ to $2 \%$ on the coast of North Africa and less than $1 \%$ in South Africa. This prevalence in sub-Saharan countries is particularly high in regions where malaria is endemic [5].

The Democratic Republic of Congo (DRC) is the third most affected country in the world by sickle cell disease after India and Nigeria. It is estimated that 20 million Congolese (i.e. $25 \%$ to $30 \%$ of the population) carry the sickle cell gene and can transmit the disease to their children and that $2 \%$ of children are born sickle cell each year in the country [6].

In the DRC, the fight against sickle cell disease is faced with certain difficulties, in particular the poor integration of control mechanisms into the health system, the lack of an inventory of the disease in all provinces, the scarcity of equipment and reagents for screening or diagnosis of sickle cell anemia, possibly related to the high cost, lack of water and electricity and the long time to report 
results. These gaps make it difficult to map this pathology [7] [8].

In Kindu (Maniema), there is no local branch of the National Program for the Fight against Sickle Cell Disease (PNLCD), so that activities to fight against sickle cell disease are not coordinated; there is also no newborn screening policy for sickle cell disease; in addition, the hemoglobin study techniques that exist there (Emmel test, alkaline $\mathrm{pH}$ electrophoresis on cellulose acetate) are not recommended for neonatal screening; therefore there are no documented data on the prevalence of sickle cell disease in this part of the country. In addition, the data available on sickle cell disease in the DRC are patchy and do not reflect the current reality in the country. The results available on neonatal screening found in 2008 by Tshilolo et al. date back 10 years and did not concern the eastern part of the country to which the town of Kindu (Maniema province) belongs. However, Agasa B. et al. observed that out of five newborns screened for homozygous sickle cell disease in Kisangani, four, i.e. 80\%, were from ethnic groups in Maniema [9].

The equipment used in the study by Tshilolo L. et al. and in that of Agasa B. et al. for neonatal screening [Isoelectrofocusing (IEF), high performance liquid chromatography (HPLC)] is not available in Kindu. Very recently, a simple, effective and affordable technique, the Sickel SCAN ${ }^{\circledR}$ Rapid Diagnostic Test (RDT), was validated in the country in the study conducted by Nsonso MD (2017), one of whose perspectives is that this RDT can be used to promote routine newborn screening programs. Faced with the lack of data on the prevalence of sickle cell disease in Kindu (Maniema) and the availability of RDT Sickle SCAN ${ }^{\circledR}$ with good intrinsic values, we decided to conduct this study on neonatal screening for sickle cell disease in the Kindu city using RDT Sickle SCAN ${ }^{\circ}$ as a technique.

The objective of this work is to determine the prevalence of sickle cell disease in newborns in Kindu and to describe the socio-demographic characteristics of newborns screened for sickle cell disease.

\section{Methods}

This is a descriptive cross-sectional study which took place over a period of two months, from June 01 to July 31, 2018. We thus systematically screened for sickle cell disease in newborns who were born in nine maternities detained in the town of Kindu, capital of the province of Maniema, eastern DRC. In 2017, the city of Kindu had a population estimated overall at 509,316 inhabitants for an area of $110 \mathrm{~km}^{2}$. It is a city that has long been landlocked in many ways. Culturally, the town of Kindu is dominated by four large tribes including the Lega estimated at $30 \%$, the Zimba at $20 \%$, the Kusu at $15 \%$, the Songola at $10 \%$ and the Bangubangu at $10 \%$. The other tribes including the Kumu, Zula, Songe, ... and others from other provinces represent $15 \%$ of the population.

Our study population consisted of newborns who were born in nine maternity hospitals selected during the study period. Was included in our study, any newborn who:

- was born in one of the nine maternities selected during the study period,

- whose parents (mother and/or father) had given their informed consent and 
- whose parents had provided us with socio-demographic data of interest.

Was excluded from our study, any newborn:

- whose sample was not correctly identified,

- whose sample in the EDTA tube was coagulated,

- whose parents withdrew their consent during the study after initially giving it to us.

We used multistage sampling. At the first stage, cluster sampling was applied. The City of Kindu was subdivided into three clusters; all the clusters were taken. The list of all the care structures integrated into the health zones with a maternity service has been established. Randomly, three structures were selected in clusters. Thus, we collected the newborns in 9 following structures: $\mathrm{CH}$ Kitulizo/BDOM, CS Alunguli, CS Kasuku 2, CS Lumbulumbu, CS Basoko, CS Mangobo, $\mathrm{CH}$ Lumbulumbu, HGR Alunguli, HGR Kindu. In each maternity unit, all newborns present during the study period were screened.

Two types of blood samples were taken: from the umbilical cord and from the heel. When the puncture was made on the heel, $5 \mu \mathrm{l}$ of blood was collected using the capillary pipette provided in the Sickle SCAN ${ }^{\circledR}$ rapid sickle cell test kit. Regardless of the type of sample, three drops of blood were collected on the $4 \mathrm{~mm}$ thick Wattman Blotter paper.

To screen for sickle cell anemia, we used the RDT Sickle SCAN ${ }^{\circ}$ which was performed instead of a sample when it was done on the heel. But when the sample was taken from the umbilical cord and stored in a tube containing EDTA, the analysis was done at the CHL laboratory. The results of newborns screened with homozygous sickle cell disease were confirmed by capillary electrophoresis (CEFA/Monkole laboratory).

The Sickle SCAN ${ }^{\circledR}$ test is a qualitative immunochromatographic test for the identification of hemoglobins $\mathrm{A}, \mathrm{S}$ and $\mathrm{C}$ by lateral flow chromatographic migration. It consists of a membrane which bears 4 bands, three of which correspond to the adsorption regions of the polyclonal anti $\mathrm{Hb} \mathrm{A}$, anti $\mathrm{Hb} \mathrm{S}$ and anti $\mathrm{Hb} \mathrm{C}$ antibodies respectively. The fourth band is the control band which contains a goat anti IgG antibody. Mouse, used as a capture antibody to form the control line. The Sickle SCAN ${ }^{\circledR}$ RDT has demonstrated good intrinsic and extrinsic values, sensitivity of $98 \%$ to $100 \%$ and specificity of $99 \%$ to $100 \%$.

The socio-demographic and biological data were encoded in an input mask on Microsoft Excel version 2007 and transposed for statistical analysis to SPSS software, Version 20.0 Windows. The variables of interest were represented in the form of figures and frequency tables and the proportion was calculated to summarize the observations.

The study protocol developed was submitted to the Ethics Committee of the School of Public Health and obtained approval under number: ESP/CE/132/2018. The various parents selected had given their informed consent.

\section{Results}

A total of 310 newborns were screened including 73 (23.5\%) at the HGR Kindu, 
$71(22.9 \%)$ at the CS Kasuku2, $51(16.5 \%)$ at the CS Basoko, $45(14.5 \%)$ at CH Kitulizo/BDOM, 33 (10.6\%) at CS Lumbulumbu, 20 (6.5\%) at HGR Alunguli, $11(3.5 \%)$ at CHL, $4(1.3 \%)$ at CS Alunguli and $2(0.6 \%)$ at CS Mangobo. In our study, out of a total of 310 newborns, 164 (53\%) were female and 146 (47\%) male, with the male/female (M/F) sex ratio at birth being $0.89 ; 265$ (85.5\%) newborns are from Maniema and 195 (62.9\%) of them were born to parents residing in Kasuku commune. The Songola, Bangubangu, Kusu, Zimba and Lega tribes taken together were in the majority among the newborns screened with $59.4 \%$ while the other tribes were represented at $40.6 \%$ (Table $1)$. As shown in Figure 1, 1.9\% (6/310) of newborns was screened for homozygous sickle cell (SS); $26.8 \%$ (83/310) were screened for heterozygous sickle cell disease (AS); 71.3\% (221/310) had normal hemoglobin status (AA). (Figure 1) The distribution by sex of the 89 newborns screened for sickle cell disease was almost equal: 44/89 (49.4\%) were female and 45/89 (50.6\%) were male (Table 2). The prevalence of sickle cell disease in the Kusu was $35.0 \%$ for heterozygotes (AS) and 2.5\% for homozygotes (SS), i.e. an overall prevalence of $37.5 \%$; Among the Lega, it was $30.4 \%$ for AS and $5.4 \%$ for SS, i.e. an overall prevalence of $35.8 \%$; among the Bangubangu, it was $21.4 \%$ for the AS, and zero for the homozygotes (Table 3 ).

Table 1. Sociodemographic characteristics of newborns.

\begin{tabular}{|c|c|c|}
\hline Variables & Effective $(\mathrm{n}=310)$ & $\%$ \\
\hline \multicolumn{3}{|l|}{ Sex } \\
\hline M & 146 & 47 \\
\hline $\mathrm{F}$ & 164 & 53 \\
\hline \multicolumn{3}{|l|}{ Province of origin } \\
\hline Bandundu & 2 & 0.6 \\
\hline Kasai & 17 & 5.5 \\
\hline Kongo Central & 5 & 1.6 \\
\hline Maniema & 265 & 85.5 \\
\hline Sankuru & 12 & 3.9 \\
\hline Sud Kivu & 5 & 1.6 \\
\hline Tshopo & 4 & 1.3 \\
\hline \multicolumn{3}{|l|}{ Township } \\
\hline Alunguli & 26 & 8.4 \\
\hline Kasuku & 195 & 62.9 \\
\hline Mikelenge & 89 & 28.7 \\
\hline \multicolumn{3}{|l|}{ Tribe } \\
\hline Songola & 9 & 2.9 \\
\hline Bangubangu & 28 & 9.0 \\
\hline Kusu & 40 & 12.9 \\
\hline Zimba & 51 & 16.5 \\
\hline Lega & 56 & 18.1 \\
\hline Others & 126 & 40.6 \\
\hline
\end{tabular}




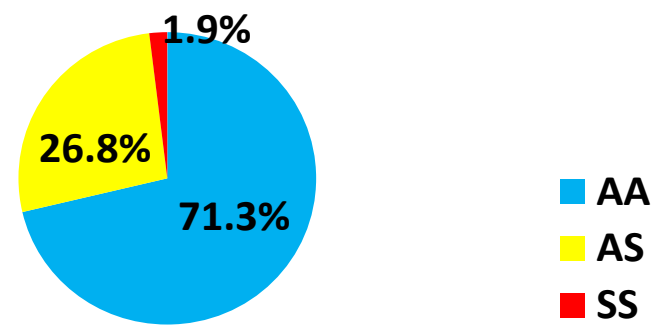

Figure 1. Types of hemoglobins found after screening.

Table 2. Distribution of the type of abnormal hemoglobin detected according to the sex of the newborns.

\begin{tabular}{ccccccc}
\hline \multirow{2}{*}{ Sex } & \multicolumn{2}{c}{ AS } & \multicolumn{2}{c}{ SS } & \multicolumn{2}{c}{ Total } \\
\cline { 2 - 7 } & Number & Prevalence & Number & Prevalence & Number & Prevalence \\
\hline Female & $40 / 89$ & $45.0 \%$ & $4 / 89$ & $4.5 \%$ & $44 / 89$ & $49.4 \%$ \\
Male & $43 / 89$ & $48.3 \%$ & $2 / 89$ & $2.2 \%$ & $45 / 89$ & $50.6 \%$ \\
Total & $83 / 89$ & $93.3 \%$ & $6 / 89$ & $6.7 \%$ & $89 / 89$ & $100 \%$ \\
\hline
\end{tabular}

Table 3. Distribution of the type of abnormal hemoglobin detected compared to the tribe of newborns.

\begin{tabular}{ccccc}
\hline \multirow{2}{*}{ Tribes } & \multicolumn{3}{c}{ AS } & \multicolumn{2}{c}{ SS } \\
\cline { 2 - 5 } & Number & Prevalence & Number & Prevalence \\
\hline Bangubangu & $6 / 28$ & $21.4 \%$ & $0 / 28$ & $0.0 \%$ \\
Kusu & $14 / 40$ & $35.0 \%$ & $1 / 40$ & $2.5 \%$ \\
Lega & $17 / 56$ & $30.4 \%$ & $3 / 56$ & $5.4 \%$ \\
Songola & $1 / 9$ & $11.1 \%$ & $0 / 9$ & $0.0 \%$ \\
Zimba & $15 / 51$ & $29.4 \%$ & $1 / 51$ & $1.9 \%$ \\
Others & $30 / 126$ & $24.4 \%$ & $1 / 126$ & $0.8 \%$ \\
Total & $83 / 310$ & $26.8 \%$ & $6 / 310$ & $1.9 \%$ \\
\hline
\end{tabular}

\section{Discussion}

Of the 310 newborns screened, 89 (28.7\%) were carriers of hemoglobin S according to the following distribution: 83 heterozygous (26.8\%) and 6 homozygous (1.9\%). We did not screen for hemoglobin $\mathrm{C}$ and this is probably due to the low relative prevalence of $\mathrm{Hb} \mathrm{C}$ in the general population in DRC [10]. This result is relatively similar to that found by Agasa B. et al. In Kisangani in 2007 on a sample slightly larger than ours (520), i.e. with $24.26 \%$ of children carrying hemoglobin S: $23.3 \%$ being heterozygous AS and $0.96 \%$ homozygous SS [9]. This could be explained by the fact that among the 520 newborns screened in Kisangani, 102 (19.6\%) belonged to tribes originating in Maniema. In Lubumbashi in 2017, Shongo MYP and Mukuku O. found in a sample of 173 newborns, a prevalence of $15.61 \%$ of hemoglobin S carriers: $12.14 \%$ were heterozygous sickle cell patients and $3.47 \%$ had a major sickle cell syndrome type SS [11]. The pilot 
study conducted in Kinshasa in 2008 by Tshilolo L et al. out of 31,204 newborns and whose samples also came from Lubumbashi, Kasai Oriental and Bas-Congo (now central Kongo) had noted a prevalence of $16.9 \%$ of heterozygous sickle cell disease (SA) and $1.4 \%$ of homozygous sickle cell disease (SS); no other abnormal hemoglobin has been identified [10]. The prevalence of SS found in our study corroborates that found by Tshilolo L et al.

In a retrospective study of neonatal screening for sickle cell disease carried out in Awka in south-eastern Nigeria from September 01, 2013 to October 27, 2017, Ejiofor OS. et al., Found a prevalence of $0.32 \%$ of SS and $24.3 \%$ of AS. [12]. The prevalence of SS found in the Nigerian study is much lower than that found in our study. This could be due to the fact that our study was carried out in the city of Kindu where the population is not sufficiently sensitized to screening for sickle cell disease before marriage and that the use of the rare screening techniques that exist (electrophoresis at alkaline $\mathrm{pH}$ on cellulose acetate, Emmel test) has not yet entered into the medical routine. As a result, in this city, couples at risk (AS + AS or AS + SS) can get married and have the probability of giving birth to children with homozygous sickle cell disease; whereas in Awka, more and more HBS carriers marry more partners with HbAA [12]. By comparing the prevalence of heterozygotes AS in newborns in our series to that reported in the adult population in DRC ( $25 \%$ to $30 \%$ ), we observe the persistence of the transmission of the tare from one generation to another within of the Congolese community. We believe that this persistence is linked to selective resistance: sickle cell disease has been selected throughout history by Plasmodium falciparum malaria; these two diseases often coexist in the same populations [13]. According to the report of the provincial coordination of the National Malaria Control Program (PNLP)/Maniema, the prevalence of malaria in Maniema was more than $40 \%$ in 2017 [14]. The prevalence of sickle cell disease found in our study is superimposable to this high prevalence of malaria in Maniema, of which the town of Kindu is the capital.

\section{Prevalence of Sickle Cell vs. Tribe}

Sickle cell disease in its heterozygous form was found in all the majority ethnic groups in the town of Kindu. This observation is similar to that made by Tchamago CJ, 2006: sickle cell disease was found in all the majority ethnic groups of Senegal without the difference being statistically significant [15]. Tshilolo L et al., Did not find either statistically significant difference between different ethno-linguistic groups with respect to sickle cell disease [10].

Among the Bangubangu newborns in our series, $21.4 \%$ were screened for sickle cell disease compared to $31.4 \%$ Zimba. The prevalence of sickle cell anemia among the Kusu was $37.5 \%$ (35.0\% AS and $2.4 \%$ SS) versus $35.8 \%$ among the Lega (30.4\% AS and 5.2\% SS). our study, the overall prevalences found in Kusu and Lega newborns were relatively higher than those found in Kisangani by Agasa B. et al., 2007 within this same category with respectively $29.9 \%$ (23.3\% 
AS and $6.6 \%$ SS) and $16.67 \%$ (12.5\% AS and $4.17 \%$ SS) [9]. This could be explained by the fact that the Lega and the Kusu are among the majority inhabitants of the urban-rural town of Kindu with $45 \%$ of the inhabitants taken as a whole. The sickle cell gene is widespread in the Indian population recognized as indigenous, living mainly in rural areas from certain groups called Castes and other classes belonging to a low socio-economic status [16].

This relatively high prevalence of homozygous sickle cell disease (SS) observed in certain tribes of Maniema, would probably be linked to endogamic marriages generally encouraged and observed in the province of Maniema in general and in the town of Kindu in particular. This type of marriage is even popular because it helps to preserve the culture and the translations from one generation to another. However, some perfectible limits emerge from this study: we haven't included in this work the medical monitoring of children screened with sickle cell disease, and that this study carried out mainly in a hospital environment.

\section{Conclusions}

The data from this study shows that sickle cell disease is indeed present in Kin$\mathrm{du}$. The prevalence of homozygous sickle cell disease found is almost similar to the theoretical prevalence as predicted by WHO in the DRC. The prevalence of sickle cell disease was high in two main tribes: Kusu and Lega. It is therefore a contribution to the development of the map of sickle cell disease in Maniema, therefore in the Democratic Republic of Congo.

This study also made it possible to observe that it is possible to make the neonatal screening for sickle cell anemia systematic in urban-rural areas by using the sickle SCAN ${ }^{\circledR}$ type RDT with good intrinsic values.

\section{Contribution of Our Study to Knowledge}

- This study provides indicative data on the extent of sickle cell disease in newborns in nine maternities in the town of Kindu, in the province of Maniema, in the eastern Democratic Republic of Congo.

- The study lays the groundwork for a systematic newborn screening program for sickle cell disease in the DRC using the Sickle SCAN ${ }^{\circledR}$ type RDT.

\section{State of Knowledge on the Subject}

Three studies have shown the prevalence of sickle cell disease in newborns in a few cities of the DRC (Kinshasa, Lubumbashi, Kisangani). This prevalence is superimposed on that of Plasmodium falciparum malaria.

\section{Contributions from Authors}

Donatien Kayembe Nzongola, Franck Nzengu-Lukusa, Léon Tshilolo Muepu, designed and coordinated the project. Antoine Lufimbo Katawandja, carried out all the manipulations. Antoine Lufimbo Katawandja and Franck Nzengu-Lukusa, wrote the article. All the authors contributed to the conduct of this work. All au- 
thors also declare that they have read and approved the final version of the manuscript.

\section{Acknowledgements}

We would like to thank the managers of the Mapon Foundation, the Lumbulumbu Hospital Center in Kindu and the CEFA/Monkole center for giving us the necessary logistics as well as the framework for the biological analyses. We would also like to thank the midwives of nine maternities in the town of Kindu as well as the Biotehchnologist Balthazard PHOBA who participated in the sampling. Finally, all our gratitude to all the parents of the town of Kindu, particularly the mothers, who voluntarily accepted and agreed to involve their babies in this study.

\section{Conflicts of Interest}

The authors declare no conflict of interest.

\section{References}

[1] Aygun, B. and Odame, I. (2012) A Global Perspective on Sickle Cell Disease. Pediatric Blood and Cancer, 59, 386-390. https://doi.org/10.1002/pbc.24175

[2] United Nations General Assembly, 73rd Plenary Session, Resolution A/RES/63/237 of December 22, 2008. https://www.un.org/fr

[3] Ouedraogo, S.O., et al. (2013) Evaluation of the Direct Medical Cost of the Management of Major Sickle Cell Syndrome in Children in Ouagadougou. Health Science, 36, 73-82.

[4] Tshilolo, L., et al. (2008) Neonatal Screening and Clinical Care Programs for Sickle Cell Disorders in Sub-Saharan Africa: Lessons from Pilot Studies. Public Health, 122, 933-941. https://doi.org/10.1016/j.puhe.2007.12.005

[5] WHO, World Health Organization (2006) Fifty-Ninth World Health Assembly, Sickle Cell Disease, April.

[6] Sickle Cell Disease: 10 Years of Mobilization against the 1st Genetic Disease in the DRC. https://www.iecd.org/

[7] PNLCD (2012) National Program for the Fight against Sickle Cell Disease: Sectoral Policy for the Fight against Sickle Cell Disease in DR Congo.

[8] Nsonso, M.D. (2017) Diagnostic Performance of the Sickle SCAN ${ }^{\circledR}$ Test in Screening for Sickle Cell Anemia at the Monkole Hospital Center in Kinshasa. End of Specialization Thesis, University of Kinshasa, Kinshasa, 58 p.

[9] Agasa, B., et al. (2010) Prevalence of Sickle Cell Disease in a Northeastern Region of the Democratic Republic of Congo: What Impact on Transfusion Policy? Transfusion Medicine, 20, 62-65. https://doi.org/10.1111/j.1365-3148.2009.00943.x

[10] Tshilolo, L., et al. (2009) Neonatal Screening for Sickle Cell Anemia in the Democratic Republic of the Congo: Experience from a Pioneer Project on 31204 Newborns. Journal of Clinical Pathology, 62, 35-38. https://doi.org/10.1136/jcp.2008.058958

[11] Shongo, M.Y.P. and Mukuku, O. (2018) Neonatal Screening for Sickle Cell Disease in Lubumbashi, Democratic Republic of Congo. Revue de P Infirmier Congolais, 2, 62-63. 
[12] Ejiofor, O.S., et al. (2018) Newborn Screening for Sickle Cell Disease (SCD) in Awka South East of Nigeria, Blood Disorders and Transfusion.

[13] Labi, D. (1994) Genetic Polymorphisms and Development of Malaria: Beyond the Case of Sickle Cell Anemia. Medicinel Science, 10, 905-906.

[14] Provincial Coordination of the National Malaria Control Program (PNLP/Maniema), 2017 Activity Report.

[15] Tchamago, C.J. (2006) Neonatal Screening for Sickle Cell Disease in Senegal. Thesis in Medicine, Cheikh AntaDiop University of Dakar, Dakar, 157 p.

[16] Dipti, S., et al. (2016) Neonatal Screening and the Clinical Outcome in Children with Sickle Cell Disease in Central India. PLoS ONE, 11, e0147081. 